\title{
PENGEMBANGAN MODUL BERBASIS MODEL PEMBELAJARAN PROBLEM SOLVING PADA TEMA 9 SUBTEMA 1 BENDA TUNGGAL DAN CAMPURAN KELAS V SD/MI
}

\author{
Sundahry ${ }^{1}$, Aldora Pratama ${ }^{2}$ \\ ${ }^{1}$ Prodi PGSD STKIP Muhammadiyah Muara Bungo \\ ${ }^{2}$ Prodi PGSD FKIP Universitas PGRI Palembang
}

Korespondensi author E-mail: dahrysundahry@gmail.com, aldorapratama@universitaspgri-palembang.ac.id

\begin{abstract}
Kata Kunci:
Pengembangan, Modul, Problem

Solving, Kelas $V$

Tujuan penelitian ini untuk: (1) Menghasilkan bahan ajar berupa modul menggunakan model pembelajaran problem solving mata pembelajaran tematik kelas V SD/MI (2) Mengetahui respon peserta didik terhadap modul menggunakan model pembelajaran problem solving pada pembelajaran tematik kelas V SD/MI. Jenis penelitian ini adalah Research and Development (R\&D) berdasarkan modifikasi yang dikembangkan oleh Sugiyono. Adapun tahapan-tahapan dalam penelitian ini dilakukan dari tahap 1 hingga tahap 7 yaitu potensi dan masalah, pengumpulan data, desain produk, validasi produk, revisi desain produk, uji coba produk, revisi produk. Pengembangan Modul Berbasis Model Pembelajaran Problem Solving Pada Tema 9 Subtema 1 Benda Tunggal dan Campuran Kelas V SD/MI dengan menggunakan Research and Development model Borg and Gall yang dimodifikasi oleh Sugiyono yang meliputi tahapan potensi dan masalah, mengumpulkan data, desain produk, validasi desain, revisi desain, uji coba produk, dan revisi produk. Respon peserta didik terhadap Modul Berbasis Model Pembelajaran Problem Solving Pada Tema 9 Subtema 1 Benda Tunggal dan Campuran Kelas V SD/MI diperoleh rata-rata skor 3,28 dengan kriteria sangat menarik. Respon pendidik terhadap Modul Berbasis Model Pembelajaran Problem Solving Pada Tema 9 Subtema 1 Benda Tunggal dan Campuran Kelas V SD/MI diperoleh rata-rata skor diperoleh skor 3,32 dengan kriteria sangat menarik. Dapat disimpulkan bahwa modul berbasis model pembelajaran problem solving pembelajaran tematik subtema tubuh manusia kelas $\mathrm{V}$ yang dikembangkan layak digunakan sebagai bahan ajar.
\end{abstract}

Keyword:

Development, Module, Problem Solving, Class V

\section{Abstrak}

\section{Abstract:}

This research was conducted with the aim of (1) producing teaching materials in the form of modules using problem solving learning models for the thematic subjects for class V SD/MI (2) Knowing student responses to modules using problem solving learning models in thematic learning for class V SD/MI. This type of research is Research and Development (R\&D) based on the modifications developed by Sugiyono. The stages in this study were carried out from stage 1 to stage 7, namely potential and problems, data collection, product design, product validation, product design revision, product testing, product revision. Module Development Based on Problem Solving Learning Model on Theme 9 Sub-theme of the Singular and Mixed Class V SD/MI by using the Research and Development model Borg and Gall modified by Sugiyono which includes stages of potential and problems, collecting data, product design, design validation, design revision, product trials, and product revisions. Student responses to the Problem Solving Learning Model-Based Module on Theme 6 Sub-theme of the Human Body Class V SD/MI obtained an average score of 3.28 with very interesting criteria. The educator's response to the Problem Solving Learning Model-Based Module in Theme 6 Sub-theme of the Human Body Class V SD/MI obtained an average score of 3.32 with very interesting criteria. It can be concluded that the module based on the problem solving learning model of the thematic learning of the fifth grade human body sub-theme that was developed is feasible to be used as teaching material. 


\section{Pendahuluan}

Pendidikan dapat diperoleh dari lembaga formal maupun non formal yang bertujuan untuk menambah ilmu pengetahuan, membentuk karakter diri, dan mengarahkan peserta didik untuk menjadi pribadi yang lebih baik. Pendidikan merupakan bagian penting dari kehidupan yang sekaligus membedakan manusia dengan makhluk hidup lainnya. Dalam pendidikan tentu terjadi proses transfer ilmu antara pendidik dan peserta didik atau yang lebih dikenal dengan pembelajaran. Upaya meningkatkan kemajuan suatu bangsa, dapat dilakukan dengan peningkatan mutu pendidikan yang berawal dari tujuan pendidikan. Pendidikan yang bermutu dapat bertujuan untuk mengembangkan potensi diri, mencakup kecerdasaan intelektual dan kepribadian yang positif. Pembelajaran merupakan perubahan tingkah laku yang kekal pada peserta didik yang disebabkan oleh pengalaman. Pengalaman menghasilkan perubahan tingkah laku dan pengetahuan sebagai upaya penting dalam mempersiapkan peserta didik untuk menjadi warga masyarakat yang baik.

Penggunaan bahan ajar sangatlah membantu guru dalam menyampaikan materi untuk meningkatkan keterlibatan peserta didik dalam proses pembelajaran. Bahan ajar merupakan bagian penting dalam proses pembelajaran yang menentukan keberhasilannya sehingga tercapai tujuan pembelajaran serta menentukan kegiatan-kegiatan pembelajaran, Menurut National Centre for competency Based Training: "Bahan ajar adalah segala bentuk bahan yang digunakan untuk membantu guru atau instruktur dalam melaksanakan proses pembelajaran dikelas. Bahan yang dimaksud bisa berupa bahan tertulis maupun tak tertulis (Andi Prastowo, 16:2015). Bahan ajar yang telah dijelaskan diatas dimaknai sebagai seperangkat bahan ajar yang disajikan secara sistematis sehingga penggunaanya dapat belajar dengan atau tanpa seseorang fasilitator atau pendidik. Modul merupakan bahan ajar berbasis cetakan yang berisi satu topik atau satu unit materi pembelajaran dengan waktu belajar untuk satu minggu yang berfungsi sebagai media belajar mandiri tanpa terpusat oleh bimbingan pendidik. Sehingga dalam pembuatan modul harus memiliki teknis sebagai berikut adanya judul modul,petunjuk umum yang meliputi (kata pengantar, daftar isi, peta konsep, glosarium, petunjuk penggunaan modul, standar kompetensi, kompetensi dasar dan sebagainya), materi modul dan evaluasi semester (Andi Prastowo, 383-384:2014).

Model-model pembelajaran dirancang untuk tujuan-tujuan tertentu, pengajaran konsep-konsep informasi, cara- 
cara berfikir, studi nilai-nilai sosial, dan sebagainya dengan meminta peserta didik untuk terlibat aktif dalam tugas-tugas kognitif dan sosial tertentu. Pembelajaran dapat dikatakan berhasil jika penerapan model yang baik dan sesuai dengan tujuan pembelajaran yang dirancang oleh seorang guru (Miftahul huda, 73:2014). Penerapan model yang baik dapat dilakukan dengan cara menyeleksi model pengajaran yang sering digunakan dalam mengajar, diantaranya: Reasoning and problem solving, inquiry training, problem based instruction, model pembelajaran perubahan konseptual, Investigation, dan diskusi kelas. Setiap strategi dan model pengajaran adalah keseluruhan metode dan prosedur yang menitikberatkan pada kegiatan peserta didik untuk mencapai tujuan tertentu (Wardhani \& Juniarso, 2019).

Dalam konteks strategi dan model pembelajaran mempunyai hambatanhambatan yang dihadapi, tujuan yang hendak dicapai, materi yang hendak di pelajari, pengalaman-pengalaman belajar prosedur evaluasi serta peran guru lebih bersifat fasilitator dan pembimbing. Strategi dan model pembelajaran yang mampu berpusat pada peserta didik adalah proses belajar mengajar berdasarkan kebutuhan dan minat peserta didik. Startegi dan model yang berpusat pada peserta didik dirancang untuk menyediakan sistem belajar yang fleksibel sesuai dengan kehidupan dan gaya belajar peserta didik. Pengajaran dapat dikembangkan secara luas dan dilaksanakan pada semua jenjang pendidikan, bahkan sering dilengkapi dengan sumber belajar untuk mengatasi hambatan-hambatan yang bersifat konvensial. Dengan strategi dan model pembelajaran diharapkan semua potensi peserta didik dapat berkembang sesuai dengan latar belakang usia dan latar belakang lainnya dari masing-masing individu peserta didik (Hoer Hamali, 201:2013). Sehingga peniliti menyimpulkan bahwa model pembelajaran sangat perlu untuk dikembangkan. Sehubungan dengan hal tersebut, salah satu alternatif yang dapat digunakan untuk meningkatkan keterampilan peserta didik adalah pembelajaran berbasis model pembelajaran problem solving.

Problem Solving adalah suatu model pembelajaran yang melakukan pemusatan pada pengajaran dan keterampilan pemecahan masalah yang diikuti dengan penguatan keterampilan. Dalam hal ini masalah didefinisikan sebagai persoalan yang tidak rutin dan belum dikenal cara penyelesainnya. Justru problem solving adalah mencari atau menemukan cara penyelesaian (menemukan pola, aturan) (Aris Shoimin,135:2013). Manfaat dalam 
menerapkan model pembelajaran Problem Solving melatih kemampun akademis peserta didik untuk belajar keras dan melatih dalam penyelesaian masalah, peserta didik mempunyai sikap kritis, kreatif sebab peserta didik diminta untuk membuat pertanyaan dari informasi yang diberikan (Via, 2015). Sehingga dalam suatu pembelajaran model problem solving sangat dibutuhkan untuk meningkatkan aktivitas berpikir peserta didik dalam mengambangkan dan memperlancar kurikulum 2013 saat ini.

Pembelajaran tematik adalah pembelajaran terpadu yang menggunakan tema untuk mengaitkan beberapa mata pelajaran. Tematik terpadu menggunakan tema sebagai pemersatu kegiatan pembelajaran yang memadukan beberapa mata pelajaran sekaligus dalam satu kali tatap muka. Demikian pula subtemanya saling berkaitan dengan yang lainnya. Proses memilih tema dan subtema bukan merupakan pekerjaan yang sulit. Namun, perlu diperhatikan bahwa tema dan subtema yang dipilih hendaknya dikembangkan lagi menjadi subtema yang lebih kontekstual dan aplikatif.

\section{METODE}

Jenis penelitian yang peneliti gunakan pada penelitian ini adalah penelitian dan pengembangan (Research and Development). Penelitian dan pengembangan merupakan proses atau metode yang digunakan untuk memvalidasi dan mengembangkan produk. Produk disini tidak hanya sesuatu yang berupa benda seperti buku teks, film untuk pembelajaran, dan software (perangkat lunak) seperti program komputer untuk pengolahan data, pembelajaran dikelas, perpustakaan atau di laboratarium.

Prosedur penelitian ini menggunakan model pengembangan yang dikembangkan oleh Borg \& Gall yang menyatakan bahwa pendekatan Research and Develovment $(\mathrm{R} \& \mathrm{D})$ dalam pendidikan meliputi sepuluh langkah. Tujuan utama metode penelitian dan pengembangan ini digunakan untuk menghasilkan produk tertentu dan mengetahui kelayakan produk yang dikembangkan. Penelitian ini mengacu pada model Borg and Gall yang dikemukakan oleh Sugiyono, model ini meliputi 1) Potensi dan masalah, 2) Pengumpulan data, 3) Desain Produk, 4) Validasi Desain, 5) Revisi Desain, 6) Uji Coba Produk, 7) Revisi Produk, 8) Uji Coba Pemakaian, 9) Revisi Produk, 10) Produk Masal. Teknik pengumpulan data: lembar observasi, lembar wawancara, lembar angket, dan dokumentasi. Teknik analisis data: Teknik analisis data pada penelitian ini menggunakan teknik analisis deskriptif kualitatif yang memaparkan hasil 
pengembangan produk yang berupa Modul.

Data yang diperoleh melalui instrumen uji coba dianalisis dengan menggunakan statistik deskriptif kualitatif. Analisis ini dimaksud untuk menggambarkan karakteristik data pada masing-masing variabel.

\section{HASIL DAN PEMBAHASAN}

Hasil penilaian validasi ahli materi tahap 1 mengalami peningkatan pada validasi ahli materi tahap 2. Adapun nilai untuk aspek kualitas isi pada tahap 1 diperoleh rata-rata skor sebesar 2,67 dengan kriteria "baik" dan pada tahap 2 rata-rata skor kualitas isi sebesar 3 dengan kriteria "baik". Aspek ketepatan cakupan pada tahap 1 diperoleh rata-rata skor sebesar 3 dengan kriteria "baik" dan pada tahap 2 diperoleh rata-rata sebesar 3,56 dengan kriteria "Sangat baik". Rata-rata skor aspek problem solving sebesar 3 dengan kriteria "baik" dan pada tahap 2 rata-rata skor

inkuiri sebesar 4 dengan kriteria "sangat baik". Dapat dilihat pada grafik 1 :

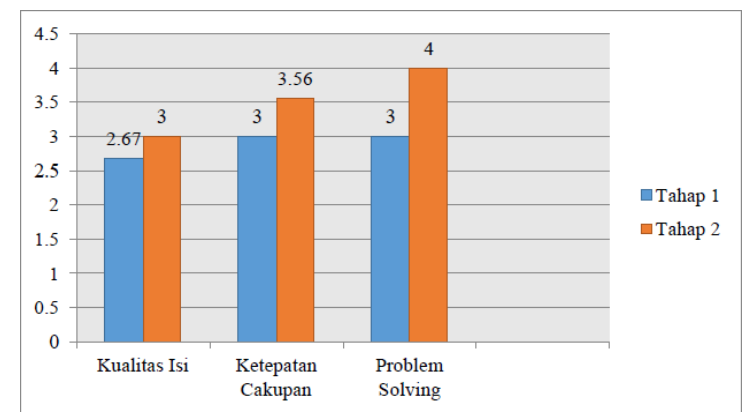

Grafik 1. Perbandingan Validasi Ahli Materi Tahap 1 dan Tahap 2
Hasil penilaian validasi ahli media tahap 1 mengalami peningkatan pada validasi ahli media tahap 2. Adapaun nilai untuk aspek ukuran Modul pada tahap 1 diperoleh ratarata skor 3 dengan kriteria "baik" dan pada tahap 2 rata-rata skor aspek ukuran Modul sebesar 3,61 dengan kriteria "sangat baik". Rata-rata skor untuk aspek desain cover Modul pada tahap 1 adalah 2,83 dengan kriteria "baik" dan pada tahap 2 rata-rata skor aspek desain cover modul sebesar 3,61 dengan kriteria "Sangat baik". Sedangkan ratarata skor aspek desain isi Modul sebesar 2,78 dengan kriteria "baik" dan pada tahap 2 rata-rata skor aspek desain isi Modul sebesar 3,69 dengan kriteria "sangat baik". Perbandingan hasil validasi ahli media pada tahap 1 dan tahap 2 dapat dilihat juga melalui grafik 2 .

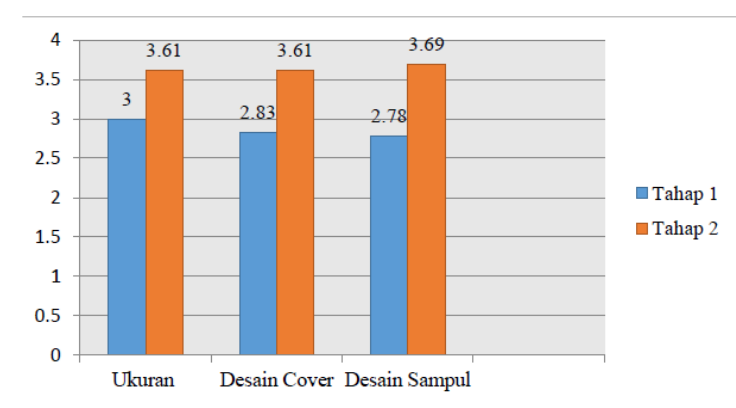

Grafik 2. Perbandingan Validasi Ahli Media Tahap 1 dan Tahap 2

Hasil penilaian validasi ahli bahasa tahap 1 mengalami peningkatan pada validasi ahli media tahap 2. Adapun nilai untuk aspek kebahasaan pada tahap 1 diperoleh rata-rata 
skor 2,75 dengan kriteria "baik" dan pada tahap 2 rata-rata skor aspek kebahasaan sebesar 3,5 dengan kriteria "sangat baik". Rata-rata skor untuk aspek ketepatan kata dan kalimat pada tahap 1 adalah 2,46 dengan kriteria "baik" dan pada tahap 2 rata-rata skor aspek ketepatan kata dan kalimat sebesar 3,39 dengan kriteria "Sangat baik". Perbandingan hasil validasi ahli media pada tahap 1 dan tahap 2 dapat dilihat juga melalui grafik 3 :

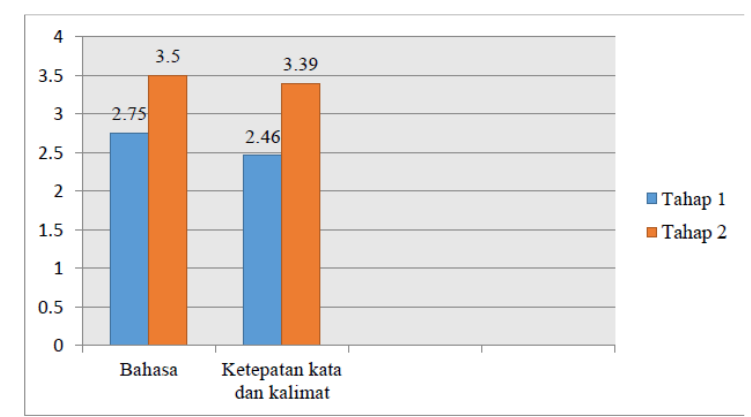

Grafik 3. Perbandingan Validasi Ahli

Bahasa Tahap 1 dan Tahap 2

Hasil uji coba terkait kemenarikan dilakukan melalui dua tahapan yaitu uji kelompok kecil dan uji lapangan mengalami peningkatan rata-rata skor pada aspeknya. Adapun hasil uji kelompok kecil diperoleh rata-rata sebesar 3,29 dengan kriteria "sangat menarik" dan pada uji lapangan dipeoleh rata-rata skor 3,33 dengan kriteria "sangat menarik".

Produk hasil pengembangan ini memiliki beberapa kekurangan sebagai berikut:

a. Modul yang dikembangkan hanya menggunakan model pembelajaran problem Solving. b. Modul ini hanya dapat digunakan oleh pendidik yang akan mengajar tematik.

c. Memerlukan biaya yang tinggi karena dalam penerapannya seluruh peserta didik harus memiliki modul.

d. Penerapanya kurang optimal karena membutuhkan waktu yang lama dalam proses pembelajarannya.

\section{KESIMPULAN}

Hasil penelitian dan pembahasan maka dapat disimpulkan bahwa dalam Pengembangan Modul Berbasis Model Pembelajaran Problem Solving Pada Tema 9 Subtema 1 Benda Tunggal dan Campuran Kelas V SD/MI layak untuk dijadikan sebagai bahan pembelajaran Tematik. Kesimpulan yang dapat diambil dari penelitian pengembangan ini adalah sebagai berikut:

1. Pengembangan Modul Berbasis Model Pembelajaran Problem Solving Pada Tema 9 Subtema 1 Benda Tunggal dan Campuran Kelas V SD/MI. dengan menggunakan Research and Development model Borg and Gall yang dimodifikasi oleh Sugiyono yang meliputi tahapan potensi dan masalah, mengumpulkan data, desain produk, validasi desain, revisi desain, uji coba produk, dan revisi produk.

2. Respon peserta didik terhadap Modul Berbasis Model Pembelajaran 
Problem Solving Pada Tema 9 Subtema 1 Benda Tunggal dan Campuran Kelas V SD/MI diperoleh rata-rata skor 3,28 dengan kriteria sangat menarik.

3. Respon pendidik terhadap Modul Berbasis Model Pembelajaran Problem Solving Pada Tema 9 Subtema 1 Benda Tunggal dan Campuran Kelas V SD/MI diperoleh rata-rata skor diperoleh skor 3,32 dengan kriteria sangat menarik.

Hendaknya dalam pembelajaran tematik tidak hanya menggunakan satu sumber belajar saja yaitu modul pembelajaran problem solving. Pemenuhan fasilitas penunjang belajar menggunakan modul berbasis model pembelajaran problem solving yang menekankan sifat mandiridalam memecahkan masalah perlu dilakukan oleh pihak-pihak pelaksana sekolah. Penelitian ini belum terlalu sempurna, semoga penelitian ini bisa menjadi referensi bagi peneliti berikutnya pada tema dan kelas yang berbeda.

\section{DAFTAR PUSTAKA}

Prastowo Andi, Pembelajaran Bahan Ajar Tematik Tinjauan Teoritis dan Praktis. (2014).Jakarta: Kencana Prenamedia Group.
Prastowo Andi, Panduan Kreatif Membuat

Bahan Ajar Inovatif.2015 Yogjakarta: Diva Press. Prastowo Andi, Pengembangan Bahan Ajar Tematik. (2014). Jakarta: Kencana.

Hamalik Oemar, Proses Belajar Mengajar. (2012). Jakarta: Bumi aksara.

Huda Miftahul, Model-Model Pengajaran dan Pembelajaran. (2014). Yogyakarta: Pustaka Pelajar.

Shoimin Aris. (2014).68 Model Pembelajaran Inovatif Dalam Kurikulum 2013.Yogyakarta: Ar-Ruzz Media.

Via, Y. (2015). Peningkatan Kemampuan Pemecahan Masalah Melalui Pengembangan Lembar Kegiatan Siswa (LKS) dengan Pendekatan Saintifik. Wahana: Tridarma Perguruan Tinggi, 64(1), 49-57.

Wardani, I. S., \& Juniarso, T. (2019). The effect of brain based learning model on student's high order thinking skills. EduHumaniora| Jurnal Pendidikan Dasar Kampus Cibiru, 11(1), 71-74. 